\title{
日本結晶学会誌
}

\section{April Vol. 542}

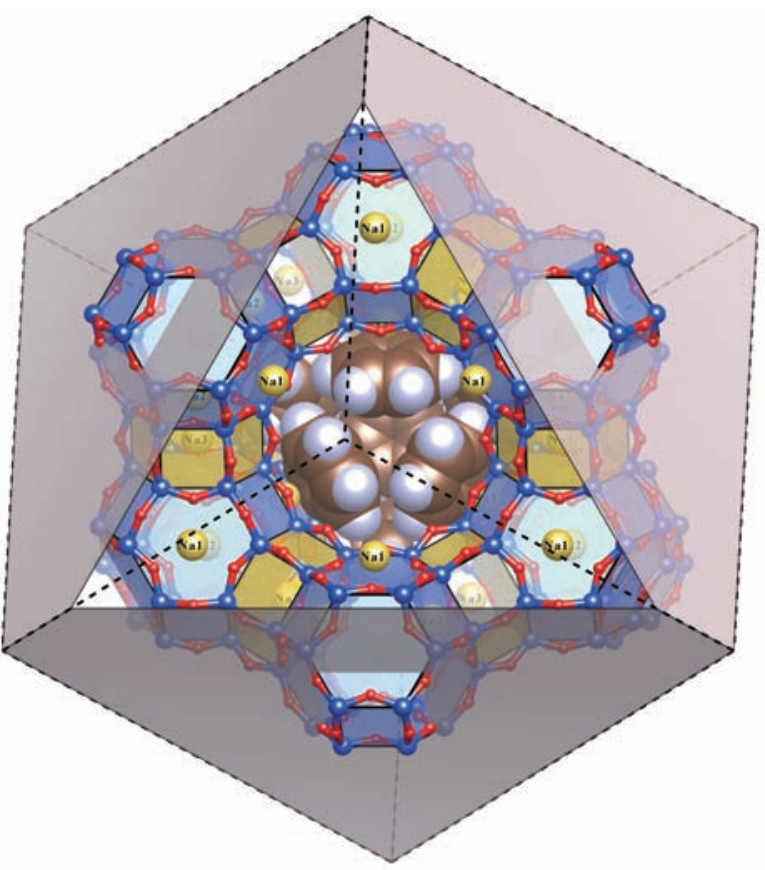

総合報告

オキシホウ酸塩蛍光体の結晶構造

最近の研究から

超臨界伸長結晶化によるナノ配向結晶体（NOC）ポリマーの 創成

ナノドメインエンジニアリングによる高性能圧電材料の創成

電子顕微鏡を用いた機能性材料の磁気微細構造解析

リチウムイオン二次電池正極材料のSTEM-EELS解析

ヒト由来Evectin-2のリン脂質結合特異性についての構造学的 洞察

抗マラリア薬の開発を指向した熱帯熱マラリア原虫由来ホス ミドマイシン標的酵素の結晶構造解析

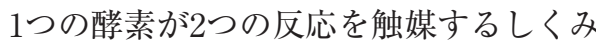

ソフトウェア情報欄

次世代三次元可視化プログラムVESTA 3 